\title{
ESTIMATING THE BENEFITS OF PASTURELAND CONSERVATION THROUGH WATER SUPPLY IMPROVEMENTS IN MONGOLIA
}

\author{
Satoru Komatsu ${ }^{1}$, Shunji Matsuoka ${ }^{2}$ and Katsuya Tanaka ${ }^{3}$ \\ ${ }^{1}$ Member of JSCE, Doctoral Student, Graduate School for International Development and Cooperation, Hiroshima \\ University \\ (Kagamiyama 1-5-1, Higashi-hiroshima 739-8529 Japan) \\ E-mail: skomatsu@hiroshima-u.ac.jp \\ ${ }^{2}$ Non-member of JSCE, Professor, Graduate School of Asia-Pacific Studies, Waseda University \\ (Nishi Waseda Bldg. 7F, 1-21-1 Nishi-Waseda, Shinjuku-ku, Tokyo 169-0051 Japan) \\ E-mail: smatsu@waseda.jp \\ ${ }^{3}$ Member of JSCE, Assistant Professor, Graduate School for International Development and Cooperation, Hiroshima \\ University \\ (Kagamiyama 1-5-1, Higashi-hiroshima 739-8529 Japan) \\ E-mail: katsuyat@hiroshima-u.ac.jp
}

This paper estimates the benefits of pastureland conservation in Mongolia using the contingent valuation method. Herders' willingness to pay (WTP) to improve water supply to expand usable pastureland areas is measured. Mongolia has experienced pastureland degradation because of livestock density near the wells; the decrease in the number of wells encourages herders to concentrate on the remaining wells. Their WTP per year for one additional hand-dug well is investigated and the effect compared with the current situation with available wells. The results show that installing wells for conserving pastureland can be a promising approach to combating desertification.

Key Words: Desertification, Pastureland Conservation, WTP, Contingent Valuation, Mongolia

\section{INTRODUCTION}

The objective of this study is to estimate the benefits of improving water supply for pastureland conservation in Mongolia, which experiences desertification caused mainly by pastureland degradation. This study attempts to measure the benefits of improving water supply in order to expand usable pastureland area for herders.

Livestock farming using pastureland has been the primary economic activity in Mongolia for centuries $^{1)}$. Herders move seasonably in the pastureland to search for better edible grass and use wells to provide water for their livestock or for their household needs.

However, available evidence indicates that overgrazing has caused pastureland degradation in Mongolia ${ }^{2)}$, where $90 \%$ of the land is categorized as pastureland. In addition, 0.73 million $\mathrm{km}^{2}$ of the Mongolian territory is at risk of desertification ${ }^{3)}$.
Recently the livestock population has increased from 25.5 million in 1991 to 33.6 million in 1999. Due to the dzud (severe winter season) in 2000-2002, the livestock number has decreased, but it steadily increased to 30.4 million in $2005^{4)}$. However, the increase in the number of livestock in itself is not the only cause of overgrazing.

In Mongolia, pastureland can support approximately 60 million sheep forage units ${ }^{1), 5}$. The Mongolians use sheep forage units as a measure to calculate the feed requirement of one sheep per year; typically, camels, cattle, and goats use five, six, and 0.9 units, respectively ${ }^{1)}$. From 1995 to 2000 , the number of livestock in terms of sheep forage units exceeded 60 million; however, it was below 60 million before 1994 and after 2001. For example, in 2005 , the pastureland feed requirement was 52.08 million forage units. In light of the recent increase in livestock and degradation of the pastureland, it can be concluded that overgrazing is not the only factor 
that affects Mongolian pastureland.

\section{(1) Causes of Pastureland Degradation in Mongolia}

Since the collapse of the socialist regime in 1991, herders are free to move their livestock; before 1991, the government regulated their movement. However, the decrease in the number of available wells has severely affected the grazing pattern. For herders, the use of wells built in the pastureland is essential both for livestock and household activities. Before 1991, a collective maintained the existing wells and installed new ones when necessary ${ }^{6}$. Since 1991, institutions that managed and maintained wells have gradually disappeared, and where there is an abundance of wells they remain in disrepair. This institutional change seriously affects the herders' livestock farming.

The decreasing number of available wells effected a reduction in usable pastureland area. During 1990-2005, the share of unused and little used pastureland in Dondgovi province (a province in the southern region of Mongolia) has increased from $33 \%$ to $40 \%$ due to shortage of water sources ${ }^{7)}$.

In Mongolia, there are two types of wells: machinery wells and traditional wells. Machinery wells can draw large amounts of water and require fuel or livestock-driven pumps to pump up water. Traditional wells are shallow hand-dug wells and require human effort to pump up water.

According to the 2005 survey of Dondgovi, only 1,302 out of 2,209 machinery wells are used ${ }^{8)}$. In addition, some wells with livestock-driven pumps, particularly the shallow wells, are destroyed and used in the same manner as traditional wells. It is uncertain how many usable wells remain of the total number of traditional wells $(1,507)$. However, most of them were dug in the $1970 \mathrm{~s}$ or $1980 \mathrm{~s}^{8)}$, and remain operational only for 20 years. This implies that they have to be rehabilitated for future use.

This process has forced herders to graze only in particular areas, resulting in a high concentration of livestock in those areas. Further, livestock grazes extensively, causing pastureland surrounding the wells to degrade and desertification to expand. Desertification is caused by the reduction of wells, followed by an increased concentration of livestock surrounding certain wells, leading to the degradation of the surrounding pastureland ${ }^{5}$. Herders do not use the desertified pastureland area, causing this vicious cycle to continue.

In that situation, herders are advised to expand the usable area for livestock grazing by increasing the number of wells in order to stop the spiral of the pastureland degradation. Usually, herders are able to utilize pastureland that contains usable wells, because water supply is an essential requirement of livestock farming. They are recommended to increase the number of traditional wells for the following reasons. First, although machinery wells are able to pump up a large amount of water, they require high maintenance and gasoline, or require suitable livestock-driven pumps, which are no longer easily available. Second, all the surveyed herders we interviewed use hand-dug wells, which implies that hand-dug wells are the most common type in use among herders.

\section{(2) Challenges of Estimating Pastureland Benefits for Combating Desertification}

Combating desertification implies that the activities involve developing the land for sustainable use in drylands. The primary aim is to (1) prevent and reduce land degradation, (2) rehabilitate partly degraded land, and (3) practice reclamation of the desertified land ${ }^{9)}$. This approach aims to decrease the density of livestock in the pastureland in order to combat desertification. Many studies have been conducted to estimate the benefits to pasturelands. For example, $\mathrm{Ma}(2002)^{10)}$ estimates the benefit of revegetation with scatterboard and fencing; the estimated benefit is derived from the agricultural products sales. However, this approach is limited to areas inhabited by sedentary livestock herders. In Mongolia where every herder needs vast areas for transhumance, and desertification is a major problem, it is recommended that the value of pastureland conservation be evaluated.

Pastureland must have water for it to be available for herders, which implies that valuation of wells in the pastureland is required. Although these values may not be tradable in a market system, contingent valuation $(\mathrm{CV})$ is a possible way to value pastureland with water for herders. $\mathrm{CV}$, then, may allow us to estimate the value to herders of conserving pastureland. CV is a method of obtaining information about preferences or willingness to pay (WTP) by asking direct questions ${ }^{11)}$. It is difficult to estimate the value of water supply improvement from productivity improvement of livestock production because it is difficult to estimate the contribution of the water supply for productivity improvement.

$\mathrm{CV}$ can elicit valid and reliable estimates of the economic value of well improvement if the respondents can clearly estimate the value of the proposed goods. Although it is only 15 years since market economy started in Mongolia, herders have experienced a market economy even in the rural areas. Herders have become quite responsive to material prices. For example, herders can get the price of livestock products from newspapers (e.g., 
Rural Business News 2006 ${ }^{12)}$ ) and choose to sell meat to the market in autumn. Regarding wells, there is the example of herders who pay a water usage fee on their livestock to agricultural cooperatives in Zavkhan province ${ }^{5)}$, which shows that herders have experienced paying a water usage fee. Because wells are essential resources for livestock and people, herders can understand the value and estimate WTP for using them.

Only a few studies have estimated the value of pasturelands. For example Lienhoop and MacMillan $(2007)^{13)}$ use the CV method to estimate the environmental costs and benefits of hydro-scheme developments in pasturelands in Iceland. However, our study takes on the challenge of evaluating the benefits of conserving pasturelands in developing countries affected by desertification. In this respect, our research has the added advantage of providing a new assessment of the benefit of combating desertification.

The overall objective of this paper is to estimate the benefits of pastureland conservation through improving water supply in order to expand usable pastureland area. The remainder of this paper is organized as follows. The next section describes the methodology and benefit assessment scenario. The third section presents the results of the survey, with a discussion of the model's validity and reliability. The final section concludes.

\section{METHODOLOGY}

\section{(1) Survey Site}

Saintsagaan town in Dondgovi province of Mongolia was selected as the study site (see Fig. 1 for location, Table 1 for main indicators). This province is situated in central Mongolia, and is considered at risk of desertification ${ }^{3)}$. Saintsagaan town comprises nine villages (bag), among which five are urban and four are rural. Around $90 \%$ of the herders live in rural places ${ }^{14)}$. A pilot survey was conducted in two rural villages (Dalai and Uizen) in June 2006. After that, the remaining two rural villages (Naran and Tersh) were selected for the main survey that was conducted in October 2006.

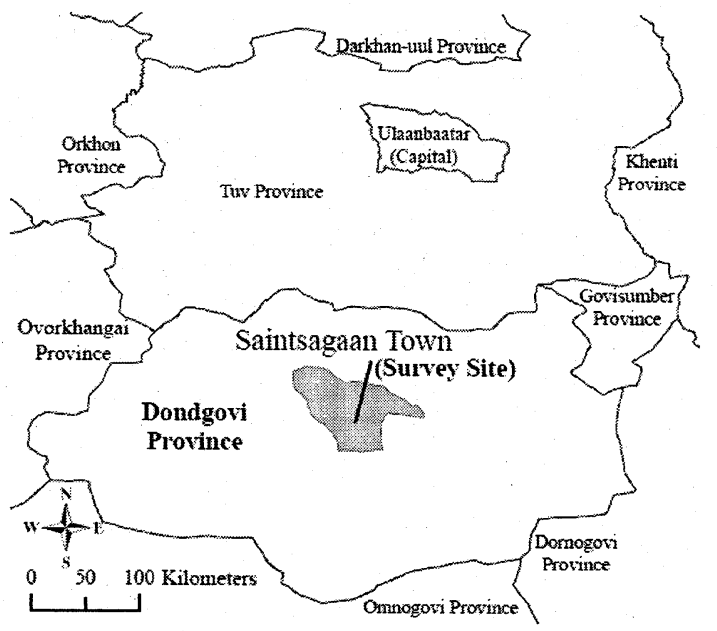

Fig. 1 Survey Site

Table1 Main Indicators in the Survey Area (2005)

\begin{tabular}{lrr}
\hline & $\begin{array}{c}\text { Dondgovi } \\
\text { Province }^{\mathrm{a}}\end{array}$ & $\begin{array}{r}\text { Saintsagaan } \\
\text { Town }^{\mathrm{b}}\end{array}$ \\
\hline Population (thousand people) & 49.6 & 13.9 \\
$\quad$ Herder Population & 16.9 & 3.8 \\
\hline Households (thousand) & 12.6 & 2.6 \\
$\quad$ Herder Households & 7.9 & 1.0 \\
\hline Number of Livestocks per & 232.2 & 192.8 \\
household (head) & & \\
\hline Livestocks (thousand head) & & \\
Total & 1829.1 & 188.6 \\
Goat & 825.4 & 87.8 \\
Sheep & 819.7 & 83.4 \\
Horse & 119.5 & 12.7 \\
Cattle & 43.8 & 3.8 \\
Camel & 20.7 & 1.0 \\
\hline
\end{tabular}

(Source) a: NSO (2006) $)^{4)}$

b: Saintsagaan Town Office $(2006)^{14)}$

\section{(2) Survey Design}

A total of 147 questionnaires were distributed. In rural Saintsagaan, every citizen is categorized as a herder. Herder households were visited randomly, with the guidance of village personnel (village governor, doctor, etc.). The questionnaire's covering letter also mentioned that this survey was conducted purely for academic purposes and that the responses would be kept confidential.

A total of 139 completed questionnaires was used for estimation after eliminating those respondents who could not understand sufficiently to answer properly, had no answer, or were protest zero bids. The scenario for which their WTP was elicited was 
an annual payment for one hand-dug well additional to the current number available to them every year. The scenario also mentioned that the herders would form groups consisting of five herder families (including the respondent's family) who would contribute to rehabilitation or the construction fee, which was a realistic situation in Mongolia. Installing a well for only one household would not be a practical solution because installing wells requires human effort. The hypothetical scenario provided for herders was as follows.

Suppose that you rehabilitate the old hand-dug wells that are currently not being used, or construct new hand-dug wells. In order to accomplish this, you organize a herder group consisting of five herder families (including your family), and you jointly rehabilitate or construct hand-dug wells. You will be able to draw the water from that well during any season of the year. As a result of your cooperation, you will be able to use one additional hand-dug well compared to your current situation. You should contribute to the rehabilitation or construction fee. The money collected from you will only be used for the rehabilitation or construction of hand-dug wells.

The results of these actions include the following:

a) expanding your grazing area that is currently unused due to lack of water sources

b) increasing your income by increasing livestock

c) saving pastureland by decreasing the density of livestock.

If the annual fee is _tugrig per household, would you be willing to pay this amount? If you are willing to pay, you will lose that same amount of your income that you now spend on other things.

The labor time required to rehabilitate a hand-dug well is slightly less than to construct a new one because rehabilitation depends on well structure, which may pose extra difficulties ${ }^{7}$. However, the expense is the same.

The double-bounded dichotomous choice questionnaire format was applied. The first bid amount offered was $5,000,10,000$, or 30,000 tugrig per household (USD $1=1,205.27$ tugrig) ${ }^{4}$. The second bid was 3,000 for rejection or 10,000 for acceptance if the first bid was 5,000. The second bid was 5,000 for rejection or 30,000 for acceptance if the first bid was 10,000 , and 10,000 for rejection or 50,000 for acceptance if the first bid was 30,000 .

\section{(3) Data}

All of the information that is considered to be affected by WTP acceptance is listed in Table 2 . Herders were asked their opinions on the status of pastureland on a scale from very well maintained (score 1) to severely degraded (score 5); all of the responses range from fairly maintained (score 3), slightly degraded (score 4), to severely degraded (score 5). They were also asked about herding (herding areas, number of wells being used, satisfaction with the number of hand-dug wells), and socioeconomic background (age, number of family members, number of children, number of elder persons, education, and household income). The number of livestock was not used for estimation because this was highly correlated with income (correlation coefficient: 0.81). The sex of the respondent was also excluded because there were no clear distinctions between the roles of males and females; both worked in livestock farming and carried water for household needs in Mongolia.

We asked them the distance from their household to the nearest usable well. This clearly revealed the state of a household's current water supply. If we found that those who lived farther away from usable wells accepted a higher bid, it is possible to assume that they supported expansion of grazing areas. Herders living far away from usable wells could install wells closer to home, which implied that the usable areas of the pastureland could be expanded.

Each household was identified by longitude and latitude using GPS (eTrex Vista, Garmin Ltd). The location of usable wells was obtained from Pacific Consultants International and Mitsui Mineral Development Engineering (2006b) ${ }^{8}$. Distance to the central Saintsagaan town was also calculated from the distance of households to the Saintsagaan town hall.

Household income was obtained from respondents' statements. Usually, herders earned money by selling livestock products (meat, wool, cashmere, etc.), but they did not consider the value of livestock products that they consumed in their households. Real income would be higher than the stated 1,597 thousand tugrig (c. USD 1,331.87) per year (annual mean). However, there were no reliable sources indicating the value of domestic consumption of livestock products in Mongolia; previous CV studies used the stated income in developing countries (e.g., Fujita et al. $2005^{15)}$ ). In addition, Oniki and $\mathrm{Xi}(2004)^{16)}$ showed that the mean household income of the herders in Khenti province (northern part of Dondgovi province) is 922 thousand in Batnorov town, 1,531 thousand in Norovlin town, and 1,607 thousand in Kherlen town. This suggests that the income level used is sufficiently reliable for estimation. 
Table2 Independent Variables Used in Regression Model (Except Bid Amount)

\begin{tabular}{|c|c|c|c|c|c|}
\hline $\begin{array}{l}\text { Variable } \\
\text { Name }\end{array}$ & Definition of Independent Variable & Mean & Std. Dev. & Min. & Max. \\
\hline AGE & Age (1: under $20,2: 20-29$, up to $6: 60$ or above) & 3.83 & 1.41 & 1 & 6 \\
\hline INC & Income (Household income, thousand tugrig per year) 1,5 & ,596.74 & $1,067.11$ & 300 & 8,500 \\
\hline DIS_CITY & Distance to the central Saintsagaan town $(\mathrm{km})$ & 22.97 & 12.68 & 3.6 & 49.9 \\
\hline DIS_WELL & Distance to the nearest working well $(\mathrm{km})$ & 1.77 & 1.00 & 0.2 & 5.9 \\
\hline NUM_FML & Number of family members & 4.42 & 2.11 & 1 & 13 \\
\hline NUM_CLD & $\begin{array}{l}\text { Number of children (under } 8 \text { and schooling age) in the } \\
\text { family }\end{array}$ & 0.59 & 0.85 & 0 & 4 \\
\hline NUM_ELD & Number of elder persons (over 65 years old) in the family & 0.47 & 0.71 & 0 & 2 \\
\hline WELL_USE & Number of wells used per year & 4.86 & 4.08 & 1 & 25 \\
\hline WELL_STS & $\begin{array}{l}\text { Satisfaction for the current number of hand-dug wells } \\
(1: \text { Yes, } 2: \text { No) }\end{array}$ & 1.76 & 0.43 & 1 & 2 \\
\hline MOVEAREA & $\begin{array}{l}\text { Moving area (1:within town, } 2 \text { : within province, } 3 \text { : } \\
\text { outside of province) }\end{array}$ & 1.61 & 0.76 & 1 & 3 \\
\hline CND_PSTR & $\begin{array}{l}\text { Opinion for the status of pastureland comparing to } 5 \text { years } \\
\text { before (1:very well maintained up to } 5: \text { severely degraded) }\end{array}$ & 4.80 & 0.43 & 3 & 5 \\
\hline EDUC & $\begin{array}{l}\text { Education (1: never, 2: primary school up to 6: } \\
\text { graduate school (where one obtains a Master, etc.)) }\end{array}$ & 2.73 & 0.88 & 1 & 4 \\
\hline
\end{tabular}

\section{(4) Estimation Method}

An indirect utility function approach proposed by Hanemann et al. $(1991)^{17)}$ is applied. This is considered the most appropriate for the double-bound dichotomous choice CV estimation method. The distribution of the WTP is assumed to be log-logistic, while the log-normal distribution is used for checking model robustness. Using the estimation program offered by Terawaki $(2002)^{18}$, the parameters to be affected for WTP acceptance, median WTP and mean WTP were estimated. The econometric software NLOGIT 3.0 (Econometric Software, Inc.) was used for estimation ${ }^{19)}$.

However, the mean WTP is not an appropriate value because the variance of mean WTP is usually large ${ }^{18)}$, and sensitive to a higher offered bid. With the exception of statistical efficiency, this scenario assumes that five herders jointly construct wells given mutual agreement. In this case, the median WTP is more appropriate because this scenario assumes the "decision by majority" social welfare function. Thus, the median WTP is used mainly for discussion and the mean WTP for reference.

\section{RESULTS AND DISCUSSION}

\section{(1) Estimation Results}

Table 3 presents the respondents' answers for the offered bid (139 samples). Table 4 shows the final results and lists the minimum value of Akaike's Information Criteria (AIC) for each combination of independent variables. Other independent variables show insignificant results for WTP acceptance. Table 5 lists the estimated WTP by using independent variables in Table 4. Estimation results are provided for the log-logistic distribution WTP because the value of AIC is smaller than for the log-normal distribution, but the significance of independent variables is about the same for either distribution.

The results show that the median WTP is 32.18 thousand tugrig (c. USD 26.70), and that the mean WTP is 33.58 thousand tugrig (c. USD 27.86). The $95 \%$ confidence interval of the median WTP is 25.69-40.30 thousand tugrig (c. USD 21.32-33.44). The results also reveal that income (logarithmic scale) is a positive inducement to accept a higher bid at the $1 \%$ significance level. 
Opinions on the status of pastureland, education, and distance to the nearest usable well show a positive influence at the $5 \%$ level. In contrast, we find that the bid amount has a negative influence on the acceptance ratio at the $1 \%$ level. The mean income of households is 1,597 thousand tugrig (c. USD 1,331.87) per year; thus, the median and mean WTP are $2.02 \%$ and $2.10 \%$ of income, respectively.

Table 3 Response for the Offered Bid

\begin{tabular}{|c|c|c|c|}
\hline First Bid & Yes / No & Second Bid & Yes / No \\
\hline \multirow{2}{*}{5,000} & \multirow{2}{*}{$44 / 4$} & 10,000 & $35 / 9$ \\
\hline & & 3,000 & $2 / 2$ \\
\hline \multirow{2}{*}{10,000} & \multirow{2}{*}{$42 /$} & 30,000 & $29 / 13$ \\
\hline & & 5,000 & $3 / 0$ \\
\hline \multirow{2}{*}{30,000} & \multirow{2}{*}{$28 / 18$} & 50,000 & $14 / 14$ \\
\hline & & 10,000 & $12 / 6$ \\
\hline
\end{tabular}

(Note) Total sample size is 139 .

Table 4 Estimation Results

\begin{tabular}{lccc}
\hline $\begin{array}{c}\text { Independent } \\
\text { Variable }\end{array}$ & Coeff. & Std. Err. & t-ratio \\
\hline Constant & 1.64 & 4.84 & 0.34 \\
CND_PSTR & $0.85^{* *}$ & 0.43 & 1.99 \\
EDUC & $0.39^{* *}$ & 0.19 & 2.03 \\
DIS_WELL & $0.41^{* *}$ & 0.20 & 2.06 \\
INC & $0.75^{* * *}$ & 0.29 & 2.61 \\
BID & $-1.75^{* * *}$ & 0.20 & -8.79 \\
\hline Log likelihood & & -136.81 \\
AIC & & 285.62 \\
\hline
\end{tabular}

(Note) Two or three asterisks indicate statistical significance at $5 \%$ and $1 \%$ level, respectively.

Table 5 Estimated WTP

\begin{tabular}{lc}
\hline Median WTP (thousand tugrig) & 32.18 \\
Mean WTP(thousand tugrig) & 33.58 \\
Median WTP (95\% confidence & $25.69-40.30$ \\
interval, thousand tugrig) & \\
\hline
\end{tabular}

We have shown that those who live farther away from the usable wells are more likely to accept a higher bid at the $5 \%$ significance level. This implies that water supply improvements farther away from the usable wells are promising, making them effective in the expansion of grazing area. If this independent variable shows no significant influence on acceptance or rejection, we must consider another scenario such as rehabilitating wells closer to each household.

The results also indicate that education is positive for accepting a higher bid; education is also important for encouraging pastureland conservation. This result also shows that the more degraded herders consider pastureland to be, the higher WTP at the $5 \%$ significance level. Encouraging consciousness of pastureland conservation and environmental education are important factors in realizing the development of wells and pastureland conservation.

The estimated median WTP as a proportion of income is $2.02 \%$. Wells are used as the source of drinking water not only for humans, but also for livestock, which makes the estimated value appear to be low. However, it confirms that the estimated values are reliable for the following reasons. First, the WTP for improving natural water sources (wells, springs, streams, or river) is low. For example, Johnson and Baltodano $(2004)^{20)}$ show that the ratio to income of the WTP to improve natural water sources is $0.61 \%$. The survey also asks respondents about their WTP to increase the number of natural water resources. As Whittington and Swarna $(1994)^{21)}$ indicate, many previous researches show the WTP for potable water supply is from $0.5 \%$ to $10 \%$, and that higher WTP can be expected if potable water is integrated in a water supply system or water quality is improved. In the rural areas of Mongolia, tap water installation or water quality improvement of wells cannot be expected. Second, according to our respondents' answers, herders typically use 4.86 wells (mean, see Table 2); they may have underestimated the utility of an additional well. We observed an insignificant relationship between the acceptance ratio and both the number of wells used and satisfaction with the current number of wells. Further research is required on this point.

The cost of installing hand-dug wells is calculated as 627.8 thousand tugrig per unit based on the estimation procedure using data from Pacific Consultants International and Mitsui Mineral Engineering $\left.(2006 \mathrm{a})^{7}\right)$, after revising fuel costs and considering transportation costs of materials from central Saintsagaan town to each well. If it is assumed that the herder groups composed of five households pay their median WTP every year, it would take around four years to repay this construction fee.

\section{(2) Validity and Reliability of the Estimation}

With contingent behavior questions, it is often impossible to observe "true" changes in activity levels under conditions identical to those existing 
when the questions were asked" ${ }^{22)}$. "Construct validity" is used to test whether the $C V$ responses are related to the variables that act as predictors of WTP, as suggested by economic theory ${ }^{22)}$. The positive/negative significance levels for accepting the higher offered bid is consistent with the herders' perceptions of their situation in Mongolia. As income is significantly positive and offered bid significantly negative, it can be concluded that these results pass the validity test.

To confirm the level of significance and the influence of the independent variables on the bid, two alternative estimation models were used. As there is no significant difference in the models' specifications, these factors also pass the validity test. Furthermore, the nonresponse rate is low (one respondent), as is that for protest zero bids (four respondents). Protest zero bids occur when the respondents reject some aspect of the constructed hypothetical scenario by reporting a zero value, even though they place a positive value on the resource ${ }^{22)}$. For example, two respondents reported, "I do see the importance of this project, but all the costs should be covered by the government." These samples are excluded from the estimation.

In terms of reliability of this survey, the herders' situation is taken into consideration in measuring WTP. One of the reasons that many economists and survey researchers have been skeptical about the reliability of CV surveys in developing countries is the presumed difficulty of understanding and interpreting respondents' answers to hypothetical questions ${ }^{23}$. Herders were not forced to respond quickly because they were given adequate time to respond to the proposed bid after due consideration. As Whittington et al. $(1992)^{24)}$ mention, respondents who are given time to evaluate the proposal put before them bid significantly less than those who do not have adequate time. This survey utilized a face-to-face approach by visiting each household. As Arrow et al. $(1993)^{25)}$ recommend, eliciting the values face-to-face is usually preferable and more reliable than mail surveys; the face-to-face method enables respondents to answer their WTP questionnaire smoothly. In addition, the enumerator bias affects the level of inconsistent results in developing countries if the enumerators are poorly trained and cannot deliver the $\mathrm{CV}$ scenario smoothly ${ }^{26)}$. This survey had only one enumerator who is employed as a lecturer in the Faculty of Economics at the Mongolian State University of Agriculture. Thus, bias caused by an untrained enumerator is not likely in the survey.

\section{CONCLUSIONS}

In this paper, the benefits to pastureland conservation in Mongolia are estimated using the contingent valuation method. Herders' willingness to pay (WTP) in order to improve water supply, thereby contributing to the expansion of usable pastureland areas, is evaluated. For that purpose, their WTP per year for one additional hand-dug well was canvassed. The result indicates that the median WTP is 32.18 thousand tugrig (c. USD 26.70) in each household.

The results show that installing wells for conserving pastureland can be a promising approach for combating desertification. The results also show that those who live farther away from the usable wells are more likely to accept a higher bid. This implies that water supply improvements for those people are an effective way to expand grazing area. These results can be applied to other arid environments subject to desertification. Arid environment regions usually have pasturelands with a low capacity to feed livestock. In order to support herders' livelihood by conserving pastureland, it is necessary to decrease the density of livestock by improving the rural water supply. This approach can provide one solution through improving herders' livelihood by supporting the development of their basic infrastructure.

There are some notable points in the practical application of the results to real projects that aim to increase the number of wells. The objective of increasing wells is to expand grazing areas and decrease livestock density; this enhances the incentive for herders to graze hitherto unused pastureland. Thus, it is very important to decide the location of newly installed wells in order to expand usable areas. Discussion and cooperation among local governments and herders, and data on wells are important factors for selecting an optimal location.

$\mathrm{CV}$ can be practiced where the herders know the offered goods and are responsive to the value change to evaluate their precise WTP. It requires careful application in developing countries, whether or not the market economy is well developed and understood in the research field.

Further research is required to apply these results in Mongolia and also to generalize them to developing countries with arid environments.

\section{ACKNOWLEDGMENTS}

We would like to express our appreciation of Baasansuren Sandui and Undarmaa Jamusran from the Mongolian State University of Agriculture for supporting the survey in Mongolia. This research is funded by the $21^{\text {st }}$ Century Centers of Excellence (COE) Program "Social Capacity Development for 
Environmental Management and International Cooperation" at Hiroshima University in Japan. It is also supported by the Global Environment Research Fund, "A Pilot Study in North-East Asia for Developing Desertification Assessment and Constructing an Early Warning System", from the Ministry of Environment, Japan.

\section{Reference}

1) Sheehy D. P.: Sustainable Livestock Use of Pastoral Resources. Bruun O. and Odgaard O. (eds.) Mongolia in Transition, Curzon Press Ltd., Surrey, Great Britain. 1996.

2) Ministry of Nature and Environment, Mongolia: National Plan of Action to Combat Desertification in Mongolia. 1997.

3) Huang S. and Sirgert F.: Land cover classification optimized to detect areas at risk of desertification in North China based on SPOT VEGETATION imagery, Journal of Arid Environments, Vol.67, Issue2, pp.308-327, 2006.

4) NSO (National Statistical Office of Mongolia): Mongolian Statistical Yearbook 2005. Ulaanbaatar, Mongolia. 2006.

5) JICA (Japan International Cooperation Agency): Ex-ante Evaluation Report of the Study on Implement Plan of Livestock Farming System in Rural Area in Mongolia 2003 (in Japanese).

6) Hanstad T. and Duncan J.: Land Reform in Mongolia: Observations and Recommendations RDI Reports on Foreign Aid and Development No.109, Seattle, Washington, 2001 .

7) Pacific Consultants International and Mitsui Mineral Development Engineering: Mongolia: The Study for Improvement Plan of Livestock Farming System in Rural Area, Final Report. Tokyo. 2006a.

8) Pacific Consultants International and Mitsui Mineral Development Engineering: Mongolia: The Study for Improvement Plan of Livestock Farming System in Rural Area, Final Report, GPS manual. Tokyo. 2006b.

9) UN (United Nations): Elaboration of an International Convention to Combat Desertification in Countries Experiencing Serious Drought and/or Desertification Particularly in Africa. General Assembly, A/AC.241/27 1994.

10) Ma Q.: Appraisal of tree planting options to control desertification: experiences from Three-North Shelterbelt Programme International Forestry Review Vol.6, Issue3-4, pp.327-334, 2004.

11) Haab T. C. and McConnell K. E.: Valuing Environmental and Natural Resources: The Econometrics of Non-Market Valuation Edward Elgar, Great Britain, 2002.

12) Rural Business News (2006) Rural Business News, 2nd Season (June- July), 2006 (in Mongolian).
13) Lienhoop N. and MacMillan D.: Valuing Wilderness in Iceland: Estimation of WTA and WTP using the Market Stall Approach to Contingent Valuation Land Use Policy, Vol.24, pp.289-295, 2007.

14) Saintsagaan Town Office: Statistics of Saintsagaan Town (Received information from town databases on October, 2006), 2006.

15) Fujita Y., Fujii A., Furukawa S., and Ogawa T.: Estimation of Willingness-to-Pay (WTP) for Water and Sanitation Services through Contingent Valuation Method (CVM) - A Case Study in Iquitos City, The Republic of Peru -, JBICI Review No.10, 2005.

16) Oniki S, and Xi S.: Regional Overgrazing and in Inner Mongolia and Mongolia: Result of Household Surveys. Journal of Rural Economics, Vol.75, No.4, pp.198-205, 2004 (in Japanese).

17) Hanemann W. M., Bloomis J., and Kanninen B.: Statistical Efficiency of Double-bounded Dichotomous Choice Contingent Valuation, American Journal of Agricultural Economics Vol. 73, No. 4, pp.1255-1263, 1991.

18) Terawaki T.: Valuing Environmental Benefits from Agriculture, Keiso-Shobo, 2002 (in Japanese).

19) Greene W. H. : NLOGIT Version 3.0 Reference Guide, Econometric Software Inc., New York, 2002.

20) Johnson, N. L. and Baltodano, M. E.: The Economics of Community Watershed Management: Some Evidence from Nicaragua Ecological Economics Vol. 49, Issue 1, pp. 57-71, 2004.

21) Whittington D., and Swarna V.: The Economic Benefits of Potable Water Supply Projects to Households in Developing Countries, Staff Paper No. 53 of Asian development Bank 1994.

22) Freeman A. M: The Measurement of Environmental and Resource Values: Theory and Methods, Resource for the Future, Washington D.C. 1993.

23) Whittington D.: Administering Contingent Valuation Surveys in Developing Countries World Development Vol.26, Issue1, pp.21-30, 1998.

24) Whittington D., Smith V. K., Okorafor A., Okore A., Liu J. L. and Mc Phail A.: Giving Respondents Time to Think in Contingent Valuation Studies: A Developing Country Application Journal of Environmental Economics and Management Vol.22, Issue3, pp.205-225, 1992.

25) Arrow K., Solow R., Portney P. R., Leamer E. E., Radner R., and Schuman H.: Report of the NOAA Panel on Contingent Valuation, 1993.

26) Whittington D.: Improving the Performance of Contingent Valuation Studies in Developing Countries, Environmental and Resource Economics, Vol.22, Issue1-2, pp.323-367, 2002.

\section{モンゴルにおける井戸供給改善を通じた牧草地保全の便益推計 小松悟・松岡俊二・田中勝也}

本研究ではモンゴルでの牧草地保全の便益を，仮想評価法 (CVM) を用いて評価した. モンゴルでは近年， 牧草地内にある井戸の水供給が減少し，牧民が残った井戸周辺で放牧を行っている，そのため，限られた井 戸周辺に牧民が集中し放牧を行うことで，牧草地が劣化し，結果砂漠化が進行している．今回利用可能な牧 草地を拡大することを通じて牧草地を保全するために，牧草地内に井戸を設置することの，牧民の支払意志 額 (WTP) を推計した. 推計の結果, 牧草地に井戸を設置することにより牧民の利用可能な牧草地が拡大し, 牧草地保全が可能であることを示した。 